\title{
My future entrepreneurial self: antecedents of entrepreneurial identity aspiration
}

\author{
Patrick Gregori, Patrick Holzmann and Erich J. Schwarz \\ Department of Innovation Management and Entrepreneurship, \\ University of Klagenfurt, Klagenfurt, Austria
}

\begin{abstract}
Purpose - Entrepreneurial identity aspiration refers to the desire to occupy an entrepreneurial role in the future and is an essential impetus for initially engaging in entrepreneurial activities. Building on identity theory, the article investigates the effects of personal attitudes, experiences and inclination towards specific practices on the strength of entrepreneurial identity aspiration.

Design/methodology/approach - This article applies multiple linear regression analysis to test the developed hypotheses on an original sample of 127 vocational college students in Austria.

Findings - Results show that risk-taking propensity, proactiveness, entrepreneurial self-efficacy and competitiveness drive entrepreneurial identity aspiration. The effects of innovativeness and need for achievement motivation are nonsignificant. Data further suggest that entrepreneurial identity aspiration is related to gender, while entrepreneurial exposure and previous entrepreneurship education show no or adverse effects.

Practical implications - Based on our findings, the authors argue that education should focus on teaching and discussing the identified attitudes and inclinations to foster the formation of entrepreneurial identities. Doing so increases students' aspirations and provides them with the necessary cognitive underpinnings for subsequent entrepreneurial action. The article suggests action-based teaching to achieve this goal.

Originality/value - This article is the first to investigate antecedents of entrepreneurial identity aspiration by connecting it to essential concepts of entrepreneurship research. The authors extend previous work on entrepreneurial identity and add to the theoretical approaches for research in entrepreneurship education. Furthermore, the article points out central aspects that should receive additional attention in educational settings.
\end{abstract}

Keywords Entrepreneurial identity aspiration, Role identity, Entrepreneurial orientation, Entrepreneurial self-efficacy, Need for achievement, Competitiveness

Paper type Research paper

\section{Introduction}

Entrepreneurship programs have become cornerstones in today's educational landscape (Holzmann et al., 2018; Nabi et al., 2017). In addition to the knowledge component of entrepreneurship education, the continuous development of an entrepreneurial identity is a vital but often neglected element in students' education (Chen et al., 2021; Donnellon et al., 2014; Edwards and Muir, 2012; Hytti and Heinonen, 2013). This apparent absence of research applying identity theory is surprising as entrepreneurial identity is an essential concept to deepen our understanding of why individuals start with and keep engaged with entrepreneurial activities (Farmer et al., 2011; Gregori et al., 2021; Murnieks et al., 2020). Studies investigating the construction of entrepreneurial identities are often restricted to individuals who are already acting entrepreneurially (Mmbaga et al., 2020; Nabi et al., 2017;

(C) Patrick Gregori, Patrick Holzmann and Erich J. Schwarz. Published by Emerald Publishing Limited. This article is published under the Creative Commons Attribution (CC BY 4.0) licence. Anyone may reproduce, distribute, translate and create derivative works of this article (for both commercial and noncommercial purposes), subject to full attribution to the original publication and authors. The full terms of this licence may be seen at http://creativecommons.org/licences/by/4.0/legalcode

Conflicts of Interest: The authors declare no conflict of interest.
My future entrepreneurial self

Received 16 February 2021 Revised 2 June 2021 2 July 2021

Accepted 14 August 2021

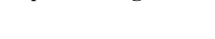


Wagenschwanz, 2020). Thus, scholars increasingly call for more work on how students form, develop and work on their identities (Edwards and Muir, 2012; Hytti and Heinonen, 2013; Liñán et al., 2018; Newbery et al., 2018). Before engaging with entrepreneurial actions, students have to desire an entrepreneurial identity (Harmeling, 2011), thus assuming the set of meanings and behaviors associated with it (Murnieks et al., 2014). Therefore, such a desire is an essential but under-researched impetus for the transition towards actual entrepreneurship (Farmer et al., 2011; Hoang and Gimeno, 2010; Seibert et al., 2020).

Entrepreneurial identity aspiration has emerged as a vibrant concept that refers to the futureoriented and subjective construction of a desired entrepreneurial identity. Identity aspiration is recognized as a catalyst making an individual inclined to perform activities and tasks integral to that possible self (Farmer et al., 2011; Seibert et al., 2020). Previous research primarily focused on the outcomes of students' entrepreneurial identity, such as the choice of education (Liñan et al., 2018) or its effect on the intention to create a venture (Pfeifer et al., 2016). However, there are no inquiries that examine the antecedents that drive students' identity aspirations (Seibert et al., 2020). The purpose of this article is to disclose such antecedents to further our understanding of what makes students aim to occupy an entrepreneurial role in the future.

Original data from 127 students suggest that the desire to become an entrepreneur is driven by an individual's perception that he or she features specific characteristics associated with the role of an entrepreneur and the individual's positive perception of being able to perform entrepreneurial tasks. Specifically, we reveal that risk-taking, proactiveness, entrepreneurial self-efficacy and competitiveness are positively associated with entrepreneurial identity aspiration. Further, we find evidence for the influence of gender and previous entrepreneurship education. Findings are contextualized and discussed in the light of earlier work to expand our understanding of entrepreneurial identity. We further offer practical implications for entrepreneurship education and close with the study's limitations that provide potential areas for future inquiries.

\section{Theoretical framework}

This article applies identity theory (Chen et al., 2021; Donnellon et al., 2014; Gregori et al., 2021; Hytti and Heinonen, 2013; Wagenschwanz, 2020). Specifically, we build on the notion of entrepreneurial identity aspiration that refers to a future but not yet realized entrepreneurial self (Farmer et al., 2011) and is rooted in the notion of possible selves. Possible selves are theorized to be future-oriented self-schemata and represent what one strives and desires to be. As cognitive manifestations, possible selves entail individually meaningful goals, aspirations and motives that function as incentives for behavior (Markus and Nurius, 1986). Individuals are encouraged to conduct activities related to a possible future identity because such activities are means to validate their envisioned identities and support the process of becoming what they have projected to be (Burke and Reitzes, 1981).

Based on role identity theory (Stryker, 1968; Stryker and Burke, 2000), entrepreneurial identity aspiration conceptualizes the possible self "entrepreneur" as a social role associated with specific assumptions and expectations. Entrepreneurial identity aspiration further assumes that individuals use this role as a basis for defining a desirable identity (Farmer et al., 2011) that guides goal-oriented behavior (Hoang and Gimeno, 2010). While a large part of identity research in entrepreneurship investigates how the entrepreneurial role is currently embodied by individuals (Cardon et al., 2013; Murnieks et al., 2014), work on identity aspiration is concerned with the formation of identities of nonentrepreneurs such as students. Empirical work investigated the relationship between identity aspiration and entrepreneurial action, showing that the strength of entrepreneurial identity aspiration is positively associated with nascent entrepreneurial behaviors of opportunity discovery and exploitation (Farmer et al., 2011; Seibert et al., 2020). 
However, the literature has remained relatively silent regarding what determines entrepreneurial identity aspiration (Seibert et al., 2020). Identity development is a continuous process of comparing role expectations with personal characteristics (Stets and Burke, 2000). For a possible self to be more central, the future role's assumptions and expectations must be congruent with the individual's self-description (Gecas, 1982; Markus and Nurius, 1986). In the case of congruency, individuals are encouraged to make progress towards the role requirements facilitating the internalization of the emergent role identity (Ashforth and Schinoff, 2016; Farmer et al., 2011; Tripathi et al., 2020). Thus, the greater the fit between the entrepreneurial role identity expectations and an individual's attributes, characteristics and typical behavior, the stronger the individual's entrepreneurial identity aspiration.

Being an entrepreneur has been connected to different aspects such as personality structure, attitudes, beliefs or practices (Murnieks et al., 2014, 2019; Seibert et al., 2020; Wagenschwanz, 2020). To answer what antecedents are crucial to strengthening the individual desire to become an entrepreneur in the future, we derive hypotheses based on aspects considered integral to an entrepreneur's role. In particular, we investigate the effects of different dimensions of entrepreneurial orientation, entrepreneurial self-efficacy, need for achievement and competitiveness.

\section{Hypotheses development}

\subsection{Individual entrepreneurial orientation}

Individual entrepreneurial orientation is concerned with a person's deep-rooted attitudes and inclination towards specific entrepreneurial practices (Covin et al., 2020; Gupta et al., 2016; Kollmann et al., 2007; Langkamp Bolton and Lane, 2012). Being an entrepreneur refers to the extent of an individual's propensity to be risk-taking, innovative and proactive (Wolfe and Shepherd, 2015). Risk-taking is defined as an individual's proclivity to take bold actions in unknown or risky situations. Innovativeness includes individuals' preferences to act in unusual, creative and experimental ways instead of already established approaches. Proactiveness describes the inclination towards forward-looking behavior such as anticipating and planning for future challenges and changes (Langkamp Bolton and Lane, 2012).

A higher individual entrepreneurial orientation leads to increased entrepreneurial activity (Kollmann et al., 2007) and is found to have a positive effect on entrepreneurship as a favored career choice (Taatila and Down, 2012) and the intention to create a new venture (Sahoo and Panda, 2019). Research has further concluded that risk-taking (Zhang et al., 2015), innovativeness (Che Embi et al., 2019) and proactiveness (Crant, 1996) are each distinct predictors for entrepreneurship that can exert influence independently (Hughes and Morgan, 2007; Lumpkin and Dess, 1996; Rezaei and Ortt, 2018). We build on this notion and operationalize entrepreneurial orientation as a disaggregated concept, where the individual dimensions are theorized as distinct constructs. Based on this, we formulate hypotheses for risk-taking, innovativeness and proactiveness. In particular, we expect that individuals for whom these dimensions are more salient have a higher aspiration towards an entrepreneurial identity because it signifies a greater overlap between self-description and role expectations. Thus, we propose:

H1a. Students with higher risk-taking scores have a stronger entrepreneurial identity aspiration.

H1b. Students with higher innovativeness scores have a stronger entrepreneurial identity aspiration.

H1c. Students with higher proactiveness scores have a stronger entrepreneurial identity aspiration. 
ET

$63,7 / 8$

\subsection{Entrepreneurial self-efficacy}

Previous research contends that entrepreneurial self-efficacy is a core characteristic of entrepreneurs that distinguishes them from other economic actors (Chen et al., 1998; Markman et al., 2005). Entrepreneurial self-efficacy refers to an individual's belief that he or she has the necessary capacity to conduct a specific entrepreneurial behavior (Chen et al., 1998) and thus the confidence to perform the role of an entrepreneur successfully (Zhao et al., 2005). This includes the belief in one's capacity to fulfill the various tasks of entrepreneurship, including the identification of business opportunities or the creation of new products and services (Boyd and Vozikis, 1994; Chen et al., 1998).

Entrepreneurial self-efficacy is positively associated with a wide range of entrepreneurship-relevant concepts such as the intention to create a new venture or entrepreneurial emotions and mental states such as passion and resilience (Newman et al., 2019). Previous studies further showed that students with a high entrepreneurial self-efficacy are more likely to view entrepreneurship as a preferable career choice (Kristiansen and Indarti, 2004) and to start a venture (Chen et al., 1998). However, the relationship between selfefficacy and entrepreneurial identity and especially entrepreneurial possible selves remains largely untouched. Prior work suspects that self-efficacy is particularly influential for the strength of possible selves (Markus and Nurius, 1986), and Pfeifer et al. (2016) show a significant positive correlation between students' entrepreneurial self-efficacy and identity aspiration. Based on this, we propose:

H2. Students with higher self-efficacy scores have a stronger entrepreneurial identity aspiration.

\subsection{Need for achievement}

Need for achievement is theorized as a psychological factor that differentiates entrepreneurs from other economic actors (McClelland, 1975; Stewart et al., 1999) and refers to an individual's desire to "accomplish something difficult. . . . To overcome obstacles and attain a high standard. To excel one's self." (Murray, 2008, p. 164).

As a motivational construct, need for achievement has also been conceptualized as an impetus for individuals to become entrepreneurs (Carsrud and Brännback, 2011; Shaver and Scott, 1992). For example, Hamilton and Harper (1994) theorized that a lack of appropriate motivation is the main obstacle preventing individuals from engaging in entrepreneurial activity, taking need for achievement to the center stage. Previous meta-analyses have revealed a significant relationship between need for achievement and the act of venture creation (Collins et al., 2004; Rauch and Frese, 2007). Based on this body of research, we argue that need for achievement is also a central factor for aspiring to an entrepreneurial role. Hence, we suggest:

H3. Students with higher need for achievement scores have a stronger entrepreneurial identity aspiration.

\subsection{Competitiveness}

The nature of the entrepreneurial activity is inherently competitive as competition with other market participants is required for dynamic entrepreneurial processes (Kirzner, 1973; Schumpeter, 1934). The entrepreneurial role is closely associated with acting in competitive situations, which is captured by individual competitiveness. Individual competitiveness refers to a person's tendency to participate in conditions of interpersonal competition and the derivation of enjoyment from such circumstances (Spence and Helmreich, 1983).

The personal inclination to accomplish more and perform better than others has been positively associated with entrepreneurship-relevant attitudes and behavior. Studies have 
unearthed a positive connection between employees' competitiveness and their preference for being self-employed (Bönte and Piegeler, 2013). Competitiveness is also connected to entrepreneurial motivation. Rajabi et al. (2018) assert that entrepreneurial motivation relies on the readiness to overcome unpredictable challenges and problems and refers to motivation as a goal orientation towards starting a new business. Based on this, the authors identified a positive relationship between competitiveness and entrepreneurial motivation. Furthermore, a student's desire to win and be better than the peers makes her or him more likely to start a business (Neneh, 2019). These results underline the importance of competitiveness for an entrepreneurial role identity, and we thus argue:

H4. Students with higher competitiveness scores have a stronger entrepreneurial identity aspiration.

In addition to the presented hypotheses, our research model includes relevant control variables. Building on previous research that identified gender as a significant predictor of entrepreneurial identity aspiration (Farmer et al., 2011), we control for gender. Furthermore, knowledge about entrepreneurship is theorized as another potential determinant (Farmer et al., 2011), resulting in the integration of students' previous entrepreneurship education experience. The exposure to entrepreneurship within the family is also positively associated with higher entrepreneurial identity aspiration (Pfeifer et al., 2016), leading us to include this control variable. Figure 1 presents the final model.

\section{Method}

\subsection{Study design}

To investigate the antecedents of entrepreneurial identity aspiration, we opted for college students because they had not yet started a business, thus providing a suitable research context. In addition, research has primarily focused on university-level entrepreneurship education. Therefore, little attention has been paid to young vocational college students

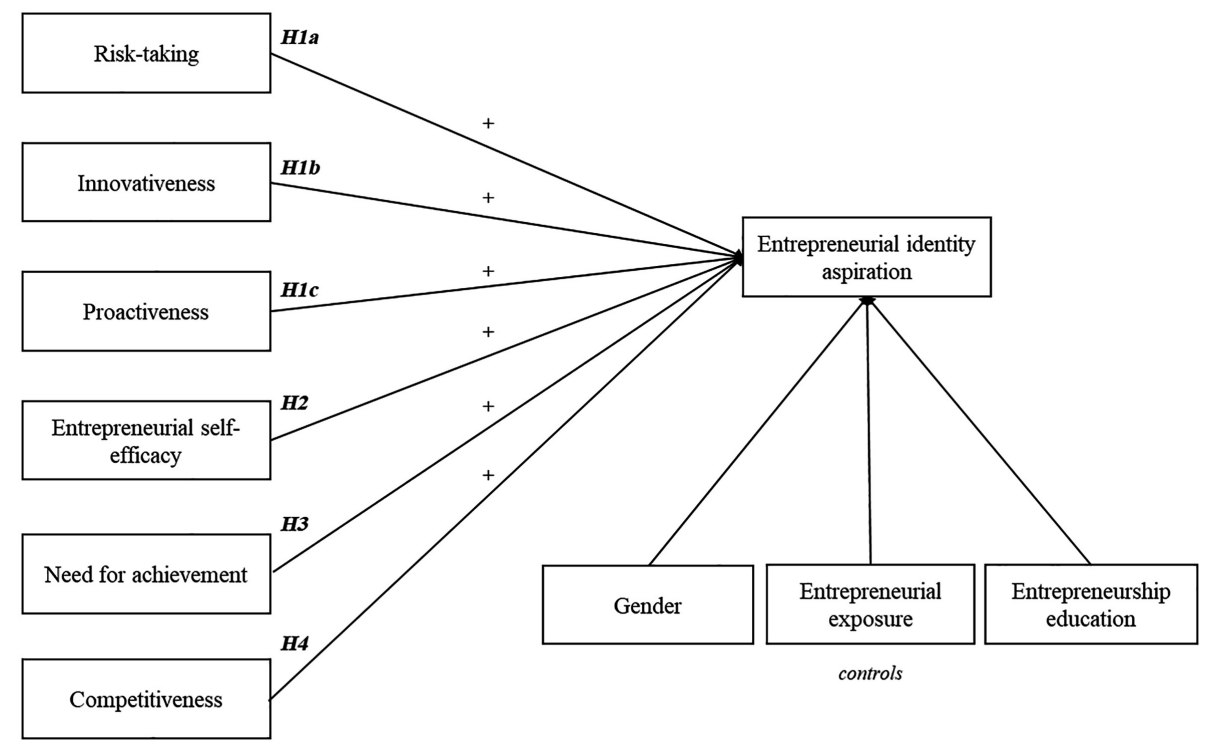

Figure 1. Research model 
(Elert et al., 2015). The Austrian education system distinguishes between the upper cycle of academic secondary schools and colleges for higher vocational education such as Secondary Colleges for Business Administration (OEAD, 2020). The curricula of these specific colleges include entrepreneurship education as one of the main teaching principles in every subject to facilitate the personality development of their students. It aims to enable individuals to take the initiative, think independently and act responsibly as entrepreneurs to shape the economy and society (Weger, 2020). Hence, these students should have an elaborated understanding of what the entrepreneurial role entails. Together with an Austrian federal state's board of education, we conducted information events to introduce our research project to entrepreneurship teachers. We identified teachers through the Junior Achievement Austria program database, a nonprofit network for entrepreneurship education. In 2019, 19 teachers were part of this network, seven of which were employed at Secondary Colleges for Business Administration, each teaching several classes in the second and fourth grades. All seven teachers agreed to contribute to the project and received additional information and the questionnaire. Teachers distributed the questionnaire to their students between October and December 2019.

\subsection{Sample and methodology}

We received a total of 133 questionnaires. Compliance with the recommended intensive data examination procedures (Hair et al., 2014) led to the exclusion of six cases due to missing values, resulting in a final sample size of 127 cases. We applied statistical power analysis (Cohen, 1992) to ex ante calculate the required sample size for our research model consisting of 11 predictors of the dependent variable. Based on the set parameters (medium effect size of $\geq 0.15$, a $5 \% \alpha$ error probability, and the recommended level of statistical power of $80 \%$ ), we calculated a minimum required sample size of 123 cases. Based on the statistical power analysis results, the final sample size of 127 respondents exceeds the required sample size to investigate the proposed research model's relationships. The final sample comprises 78 females $(61.4 \%$ ) and 49 males (38.6\%), representing $14 \%$ of the overall population and closely matching the population's gender distribution (54\% female, $46 \%$ male). Respondents' age ranges from 15 to 19 years, with an average of 16.6 years $(\mathrm{SD}=1.17)$. Further sample characteristics are reported in Table 1.

Our model investigates the relationships between individual experiences, motivations, perceptions and aspirations. Since these determinants cannot be accurately observed externally, we opted for a single-informant study design. We aimed to reduce the probability of common method bias by implementing several a priori measures (Podsakoff et al., 2003). We assured the respondents of an anonymous data collection and asked them to provide honest answers to avoid socially desirable responses. In developing the questionnaire, we emphasized short, focused and simple items that respondents could answer spontaneously. Furthermore, we formulated fact-based statements (for example, "I often think about becoming an entrepreneur") to elicit the respondents' consent. We further applied Harman's single factor test (Harman, 1967) to analyze the probability of common method bias ex-post. We thus performed an exploratory factor analysis that included all multi-items used. The unrotated solution of this factor analysis extracted seven factors with eigenvalues $>1$, and none of the factors explained most of the variance.

\subsection{Measures}

We used reflective multi-item measures with seven-point Likert-type scales for multivariate constructs. All used Likert-scales reflected the agreement with the item $(1=$ strongly disagree to $7=$ strongly agree) except for the self-efficacy scale, which asked for the individuals' confidence concerning completing specific tasks $(1=$ not confident to 


\begin{tabular}{|c|c|c|c|c|c|c|}
\hline & Number & Percentage & & Number & Percentage & entrepreneurial \\
\hline Gender & & & $\begin{array}{l}\text { Entrepreneurship education } \\
\text { (Business ideas) }\end{array}$ & & & \\
\hline Male & 49 & 38.6 & 1 & 10 & 7.9 & \\
\hline \multirow[t]{2}{*}{ Female } & 78 & 61.4 & 2 & 13 & 10.2 & \\
\hline & & & $\begin{array}{l}3 \\
4\end{array}$ & $\begin{array}{r}9 \\
32\end{array}$ & $\begin{array}{r}7.1 \\
25.2\end{array}$ & 1181 \\
\hline Age & & & 5 & 17 & 13.4 & \\
\hline 15 & 25 & 19.7 & 6 & 18 & 14.2 & \\
\hline 16 & 38 & 29.9 & 7 & 28 & 22.0 & \\
\hline 17 & 37 & 29.1 & & & & \\
\hline 18 & 17 & 13.4 & $\begin{array}{l}\text { Entrepreneurship education } \\
\text { (Business modeling) }\end{array}$ & & & \\
\hline 19 & 10 & 7.9 & 1 & 5 & 3.9 & \\
\hline & & & 2 & 7 & 5.5 & \\
\hline & & & 3 & 18 & 14.2 & \\
\hline $\begin{array}{l}\text { Entrepreneurial } \\
\text { exposure parents }\end{array}$ & & & 4 & 16 & 12.6 & \\
\hline No & 100 & 78.7 & 5 & 28 & 22.0 & \\
\hline \multirow[t]{2}{*}{ Yes } & 27 & 21.3 & 6 & 31 & 24.4 & \\
\hline & & & 7 & 22 & 17.3 & Table 1. \\
\hline Note(s): $n=127$ & & & & & & Sample descriptives \\
\hline
\end{tabular}

$7=$ completely confident). The complete list of items is provided in the Appendix. We relied on established constructs from the literature to measure entrepreneurial identity aspiration (Farmer et al., 2011), risk-taking, proactiveness and innovativeness (Langkamp Bolton and Lane, 2012), self-efficacy (Zhao et al., 2005), need for achievement (Liu et al., 2010) and trait competitiveness (Helmreich and Spence, 1978). We adapted the items slightly to better fit our study's context.

Furthermore, we controlled for age and gender $(0=$ female; $1=$ male $)$ and added items to control for the effects of previous entrepreneurship education. For the latter, we asked the respondents how often they were confronted with entrepreneurship-related concepts (startup ideas and business models) during the last school year. In line with other studies (Gird and Bagraim, 2008), we added dichotomous items to control for entrepreneurial exposure that asked the respondents if their parents had owned a business while the respondents were growing up $(0=$ no; $1=$ yes $)$.

\subsection{Scale properties}

To check the scales' validity and reliability, we conducted various tests. The Cronbach's alpha coefficients range from 0.57 to 0.93 and are, therefore, only partially satisfactory. Thus, we further calculated composite reliability scores that are less strongly influenced by the scale's number of items (Netemeyer et al., 2003). Composite reliability scores range from 0.76 to 0.93 and support the scales' internal consistency. In the next step, we tested for the scales' unidimensionality by performing principal component analyses with varimax rotation. We conducted this step for the items of each construct separately, and unidimensionality was confirmed as we extracted only one factor for each construct with eigenvalues $>1$ (Hair et al., 2014). Finally, we calculated the variance inflation factors (VIF) to identify any potential multicollinearity. All scores are below 2.6, indicating that multicollinearity is not an issue (O’brien, 2007). 
ET

$63,7 / 8$

Table 2 shows the means, standard deviations, correlations and alpha coefficients. The list of reflective items, including factor loadings, composite reliability and average variance extracted, is provided in the Appendix.

\section{Results}

We applied multiple linear regression to test the proposed hypotheses. Table 3 shows the results of the regression.

The base model that includes only the covariates shows that entrepreneurial exposure through parents positively affects the identity aspiration; this effect, however, becomes nonsignificant when including the main predictors to the main model. In the next step, we added the direct effects of the main predictors. Results indicate that risk-taking $(\beta=0.19$; $p=0.03)$, proactiveness $(\beta=0.28 ; p<0.001)$, self-efficacy $(\beta=0.40 ; p<0.001)$ and competitiveness $(\beta=0.23 ; p<0.001)$ have positive effects on entrepreneurial identity aspiration. The empirical data thus support hypotheses 1a, 1c, 2 and 4. However, innovativeness $(\beta=-0.18 ; p=0.08)$ and need for achievement $(\beta=-0.14 ; p=0.13)$ appear to have no effect on entrepreneurial identity aspiration, thus, hypotheses $1 \mathrm{~b}$ and 3 are not supported by the data. The model explains $45 \%$ (Adj. $R^{2}=0.40$ ) of the variance in entrepreneurial identity aspiration, which indicates an increase of $33 \%$ compared to the base model. Furthermore, by adding the main predictors, the model fit also increases significantly $(\Delta F=11.68, p<0.001)$. A summary of the tested hypotheses is provided in Table 4 .

\section{Discussion}

Our research model revealed novel insights into the antecedents of entrepreneurial identity aspiration. By discussing these results, we add to a deeper understanding of the personal attitudes, experiences and inclination towards specific practices that relate to students' desire for a future entrepreneurial self.

Based on the concept of individual entrepreneurial orientation (Goktan and Gupta, 2015; Gupta et al., 2016), we can show that risk-taking and proactiveness add to students' strength of identity aspirations. Previous work on entrepreneurial identity largely remained silent about these aspects (Cardon et al., 2013, 2017; Mmbaga et al., 2020), which we show to be integral for the desire to assume an entrepreneurial identity. We did not find support for the theorized positive effects of innovativeness. The absence of this connection is surprising, given the extensive body of the literature emphasizing the role of innovativeness for entrepreneurial orientation in general (Covin and Slevin, 1989; Kollmann et al., 2007) and entrepreneurial identities in particular (Cardon et al., 2013; Hoang and Gimeno, 2010; Murnieks et al., 2019). This indicates that a student's propensity towards experimentation, unusual approaches, novel projects or new activities (Langkamp Bolton and Lane, 2012) does not necessarily lead to identity aspiration.

We can further show the positive connection between entrepreneurial self-efficacy and entrepreneurial identity aspiration. Although the potential relationship between self-efficacy and possible selves was first mentioned more than three decades ago (Markus and Nurius, 1986), this study is the first to provide empirical support for this link contributing to identity theory in entrepreneurship. This finding further supports previous work emphasizing the importance of confidence in entrepreneurship education (Dinis et al., 2013; Pruett and Şeşen, 2017). Based on our data, we can show that higher self-confidence of students in their ability to fill out the entrepreneur's role leads to a higher aspiration to make this role a part of their identity. Thus, self-efficacy can be a marker for progress towards the future possible entrepreneurial self, increasing its desirability (Tripathi et al., 2020), making it essential for educational initiatives to develop this self-efficacy (Florin et al., 2007). 


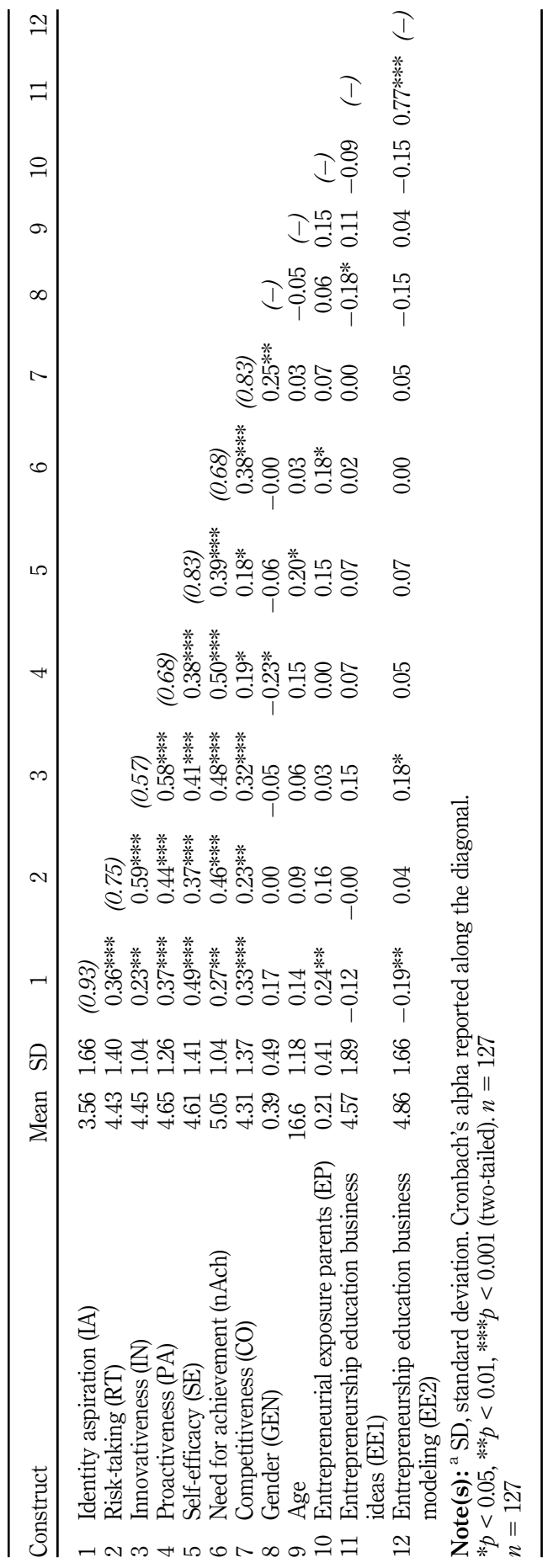




\section{ET \\ $63,7 / 8$}

1184

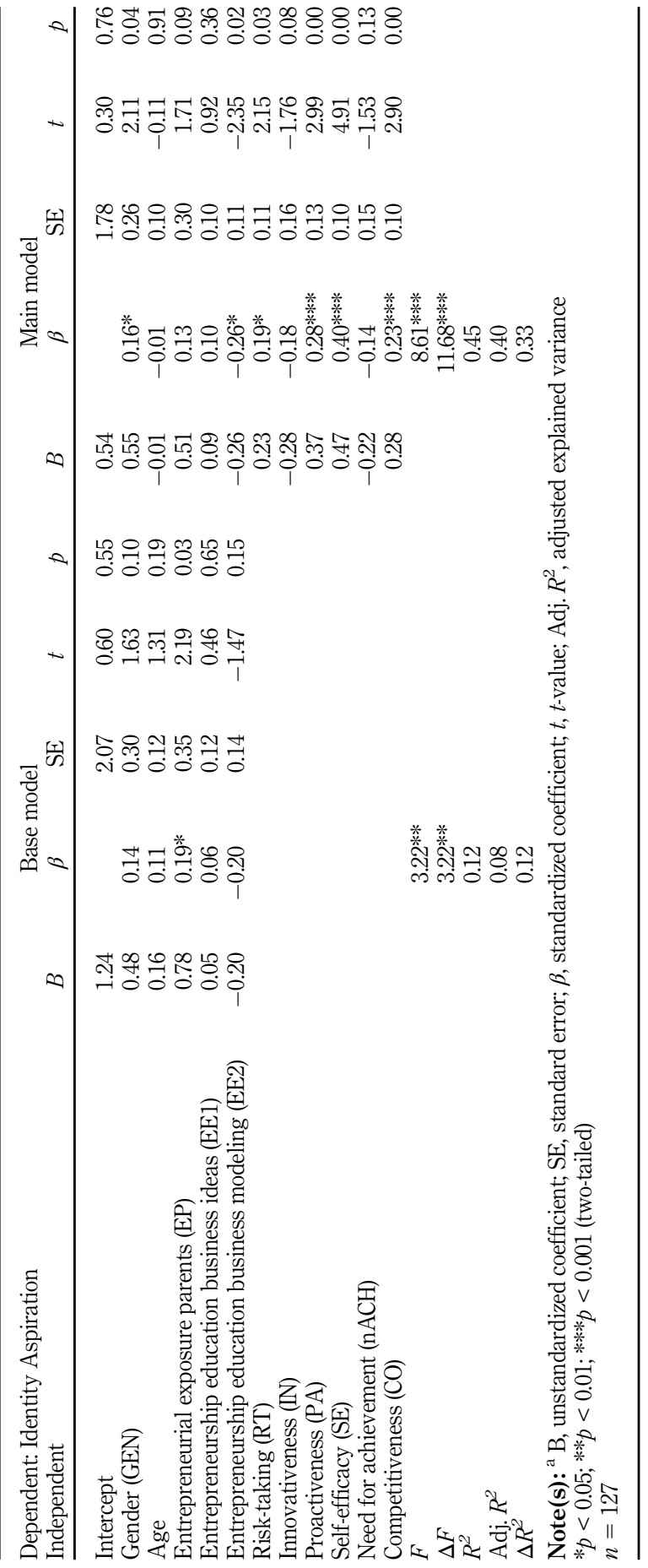

Table 3.

Results of regression models $^{\mathrm{a}}$ 


\begin{tabular}{|c|c|c|}
\hline Hypothesis & Result & \\
\hline $\begin{array}{l}\text { H1a: Students with higher risk-taking scores have a stronger entrepreneurial identity } \\
\text { aspiration }\end{array}$ & Supported & \\
\hline $\begin{array}{l}\text { H1b: Students with higher innovativeness scores have a stronger entrepreneurial identity } \\
\text { aspiration }\end{array}$ & Not supported & \\
\hline $\begin{array}{l}\text { H1c: Students with higher proactiveness scores have a stronger entrepreneurial identity } \\
\text { aspiration }\end{array}$ & Supported & 1185 \\
\hline $\begin{array}{l}\text { H2: Students with higher self-efficacy scores have a stronger entrepreneurial identity } \\
\text { aspiration }\end{array}$ & Supported & \\
\hline $\begin{array}{l}\text { H3: Students with higher need for achievement scores have a stronger entrepreneurial identity } \\
\text { aspiration }\end{array}$ & Not supported & \\
\hline $\begin{array}{l}\text { H4: Students with higher competitiveness scores have a stronger entrepreneurial identity } \\
\text { aspiration }\end{array}$ & Supported & $\begin{array}{r}\text { Summary of tested } \\
\text { hypotheses }\end{array}$ \\
\hline
\end{tabular}

Despite the rich tradition of seminal works that postulate the importance of need for achievement as a decisive factor for potential entrepreneurial behavior (Collins et al., 2004; McClelland, 1975; Stewart et al, 1999), it did not hold the expected positive effect for entrepreneurial identity aspiration. This might be due to the notion that need for achievement comes into play depending on how it is encoded in the future possible self (Markus and Nurius, 1986). It is comprehensible that a higher need for achievement motivates students to achieve a self-defined possible future self in general, but its effect on the strength of a specific entrepreneurial future self might not be as relevant as expected. This result is somewhat contradictory to previous research that identified achievement motivation as one of the core aspects to foster entrepreneurial drive in young college students (Dinis et al., 2013; Florin et al., 2007).

Our results further add to establishing a link between individual competitiveness and entrepreneurial identity aspiration. Recent research suggests that acting in competitive situations is central for entrepreneurial identities and a source of strong positive feelings for entrepreneurs (Cardon et al., 2017). This discussion, however, focuses on individuals that are already acting as entrepreneurs. We add to these findings by showing that an inclination towards competition with others is also relevant for students' formation of a future possible entrepreneurial self.

The results further illustrate the importance of gender for entrepreneurial identities (Mmbaga et al., 2020) as students who declare themselves as male exhibit a higher entrepreneurial identity aspiration than females. Previous research posits that entrepreneurship is more often associated with male role models and masculine traits (Ahl, 2006), and that females perceive the barriers of becoming entrepreneurial as more deterring than males (Şeşen and Pruett, 2014). Hence, male students might find it easier to identify themselves with the entrepreneurial role leading to higher aspirations.

Our study shows that entrepreneurial exposure has no significant effect on identity aspiration. This stands in sharp contrast to the prominent notion that entrepreneurial experience, such as self-employed parents, per se has positive effects (Mungai and Velamuri, 2011). Previous entrepreneurship education pertaining to business ideas also has no effect, and entrepreneurship education in terms of business models is even negatively associated with identity aspiration. Taken together, our results point towards the need for a more nuanced understanding of how students evaluate and value specific experiences (Zapkau et al., 2017).

\section{Implications}

\subsection{Implications for theory}

Our findings have two main implications for identity theory and research in entrepreneurship education. First, we extend previous work on identity in entrepreneurship research. 
By connecting and discussing the notion of possible entrepreneurial selves with established concepts of entrepreneurship research, we add to the theoretical development of entrepreneurial identity aspiration and extend the context in which it is applicable (Farmer et al., 2011; Pfeifer et al., 2016; Seibert et al., 2020). This study is the first to unravel what determines the desirability of the entrepreneurial role as a possible self, expanding the literature on what constitutes entrepreneurial identity and motivates individuals to become entrepreneurial (Cardon et al., 2017; Krueger, 2007; Mmbaga et al., 2020; Murnieks et al., 2020). In this respect, our quantitative study adds to largely conceptual and qualitative efforts of identity theory in entrepreneurship (Chen et al., 2021; Mmbaga et al., 2020; Wagenschwanz, 2020).

Second, we present an alternative theoretical foundation for researching students' motivation to become entrepreneurial. The construction of an entrepreneurial identity has become an essential topic (Donnellon et al., 2014; Edwards and Muir, 2012), but entrepreneurship education is still dominated by research on students' intention to set up a business (Nabi et al., 2017). We show that entrepreneurial identity aspiration is a concept that can illuminate the desire of students to become entrepreneurs, contributing to the call for more diverse theory-driven research in entrepreneurship education (Fayolle, 2013). Thereby, our study identified integral aspects of how these possible entrepreneurial selves are formed and thus adds to our knowledge of constructing identities as a pedagogical objective (Chen et al., 2021; Edwards and Muir, 2012). Specifically, we contribute to a deeper understanding of students' characteristics and how they relate to self-identity (Dinis et al., 2013; Edwards and Muir, 2012; Florin et al., 2007; Pruett and Şeşen, 2017).

\subsection{Implications for practice}

This study further has implications for educators and policymakers that plan to present the role "entrepreneur" as a worthwhile career path. Based on our findings, we argue that curricula should focus on teaching and discussing the attitudes and inclination towards specific practices, such as risk-taking, proactiveness, self-efficacy and competitiveness, necessary to fill the entrepreneurial role. Fostering these through educational initiatives increases the students' identity aspiration and also provides them with the necessary cognitive underpinnings for subsequent entrepreneurial action (Bandera et al., 2020).

Previous work often focused on role models to form students' identities (Donnellon et al., 2014; Newbery et al., 2018). However, using role models for educational purposes is also a double-edged sword because they are often conveyed through media in a sensational way that distorts the content of everyday entrepreneurial behavior (Newbery et al., 2018; Swail et al., 2014). Increasing students' ambitions, aspirations and intentions without changing the cognitive underpinnings and the necessary skills can yield negative outcomes (Bandera et al., 2020; Nabi et al., 2017). As such, we advocate for education to consider the identified concepts to promote positive self-conceptions and confidence (Pruett and Şeşen, 2017) that lead to entrepreneurial identity aspiration in a more sustainable way. Traditional classroom settings prevalent in entrepreneurship education are less likely to result in authentic learning processes, which are needed to foster entrepreneurial propensities (Kassean et al., 2015). Thus, to address the identified deep-rooted attitudes and inclinations of students, we support the call for entrepreneurship education that is action-oriented and linked to real-life situations (Neck et al., 2014). Education, then, can serve as an experimental space for students to explore concepts through personal experience that results in possibilities for learning and identity construction going beyond the mere accumulation of knowledge (Donnellon et al., 2014; Harmeling, 2011), which is especially important for teenagers with their specific needs and expectations (Dinis et al., 2013; Liñán et al., 2018). 


\section{Limitations and future research}

Like every scholarly work, our inquiry has limitations that provide avenues for future research. The investigated concepts may evolve over time, and the cross-sectional design applied has limitations in this regard. We advise further work to build on our results and conduct studies to test the proposed relationships. Such designs could take account of the self-reinforcing mechanisms of identities. Individuals act in ways that are congruent with the desired future self (Burke and Reitzes, 1981). Thus, it is feasible that higher entrepreneurial identity aspiration encourages students to behave in ways that lead to increasing aspiration over time (e.g. take specific courses). To further elucidate the potential reciprocity of the analyzed concepts, future research can also incorporate interviews with students to gain insights into their personal experience of identity development.

We built our model on well-established constructs that are tightly connected to entrepreneurial identities (Anderson and Warren, 2011; Seibert et al., 2020). However, other concepts also might be central to explaining how the role "entrepreneur" becomes more meaningful for students. Future research could, for instance, connect entrepreneurial identity aspiration to the literature on entrepreneurial passion (Cardon et al., 2013) and explore how passion for specific activities might fuel the identity aspiration of students. Furthermore, we controlled for gender, entrepreneurial exposure and education, but these aspects warrant additional attention in future research. For instance, future endeavors can investigate genderspecific constructions of entrepreneurial identities (Hytti and Heinonen, 2013), how different forms of entrepreneurial exposure are evaluated (Zapkau et al., 2017), or the content, methods and environment of entrepreneurship education and learning (Lattacher et al., 2021; Nabi et al., 2017) and their effects on the aspiration of students.

Moreover, our research focused on identity aspiration and thus on the role "entrepreneur" as a desirable possible self that provides a meaningful goal and motivation for the individuals. However, the notion of possible selves also allows for cognitive manifestations of selves one does not want to become, resulting in perceived threats and fears (Markus and Nurius, 1986). The act of distancing from specific types of identities is integral for constructing entrepreneurial identities (Gregori et al., 2021). To expand theories of entrepreneurial identity, future research can explore how students evaluate different role identities (e.g., employee, student, researcher, etc.), and how this influences their entrepreneurial identity aspiration.

\section{References}

Ahl, H. (2006), "Why research on women entrepreneurs needs new directions", Entrepreneurship Theory and Practice, Vol. 30 No. 5, pp. 595-621.

Anderson, A.R. and Warren, L. (2011), "The entrepreneur as hero and jester: enacting the entrepreneurial discourse", International Small Business Journal: Researching Entrepreneurship, Vol. 29 No. 6, pp. 589-609.

Ashforth, B.E. and Schinoff, B.S. (2016), "Identity under construction: how individuals come to define themselves in organizations", Annual Review of Organizational Psychology and Organizational Behavior, Vol. 3 No. 1, pp. 111-137.

Bandera, C., Santos, S.C. and Liguori, E.W. (2020), "The dark side of entrepreneurship education: a delphi study on dangers and unintended consequences", Entrepreneurship Education and Pedagogy, Advance online publication, p. 1-28.

Bönte, W. and Piegeler, M. (2013), "Gender gap in latent and nascent entrepreneurship: driven by competitiveness”, Small Business Economics, Vol. 41 No. 4, pp. 961-987.

Boyd, N.G. and Vozikis, G.S. (1994), "The influence of self-efficacy on the development of entrepreneurial intentions and actions", Entrepreneurship Theory and Practice, Vol. 18 No. 4, pp. 63-77.

\section{My future entrepreneurial self}

1187 
ET

$63,7 / 8$

1188

Burke, P.J. and Reitzes, D.C. (1981), "The link between identity and role performance", Social Psychology Quarterly, Vol. 44 No. 2, pp. 83-92.

Cardon, M.S., Gregoire, D.A., Stevens, C.E. and Patel, P.C. (2013), "Measuring entrepreneurial passion: conceptual foundations and scale validation", Journal of Business Venturing, Vol. 28 No. 3, pp. 373-396.

Cardon, M.S., Glauser, M. and Murnieks, C.Y. (2017), "Passion for what? Expanding the domains of entrepreneurial passion", Journal of Business Venturing Insights, Vol. 8, pp. 24-32.

Carsrud, A. and Brännback, M. (2011), "Entrepreneurial motivations: what do we still need to know?", Journal of Small Business Management, Vol. 49 No. 1, pp. 9-26.

Che Embi, N.A., Jaiyeoba, H.B. and Yussof, S.A. (2019), "The effects of students' entrepreneurial characteristics on their propensity to become entrepreneurs in Malaysia", Education + Training, Vol. 61 Nos 7-8, pp. 1020-1037.

Chen, C.C., Greene, P.G. and Crick, A. (1998), "Does entrepreneurial self-efficacy distinguish entrepreneurs from managers?”, Journal of Business Venturing, Vol. 13 No. 4, pp. 295-316.

Chen, S.H., Wang, W.T. and Lu, C.T. (2021), "Exploring the development of entrepreneurial identity in a learning-by-doing entrepreneurial project environment", Education + Training, Advance online publication, pp. 1-22.

Cohen, J. (1992), “A power primer”, Psychological Bulletin, Vol. 112 No. 1, pp. 155-159.

Collins, C.J., Hanges, P.J. and Locke, E.A. (2004), "The relationship of achievement motivation to entrepreneurial behavior: a meta-analysis", Human Performance, Vol. 17 No. 1, pp. 95-117.

Covin, J.G. and Slevin, D.P. (1989), "Strategic management of small firms in hostile and benign environments", Strategic Management Journal, Vol. 10 No. 1, pp. 75-87.

Covin, J.G., Rigtering, J.P.C., Hughes, M., Kraus, S., Cheng, C.F. and Bouncken, R.B. (2020), "Individual and team entrepreneurial orientation: scale development and configurations for success", Journal of Business Research, Vol. 112, pp. 1-12.

Crant, M.J. (1996), "The proactive personality scale as a predictor of entrepreneurial intention”, Journal of Small Business Management, Vol. 34 No. 3, pp. $42-49$.

Dinis, A., do Paço, A., Ferreira, J., Raposo, M. and Gouveia Rodrigues, R. (2013), "Psychological characteristics and entrepreneurial intentions among secondary students", Education + Training, Vol. 55 Nos 8-9, pp. 763-780.

Donnellon, A., Ollila, S. and Williams Middleton, K. (2014), "Constructing entrepreneurial identity in entrepreneurship education", The International Journal of Management Education, Vol. 12 No. 3, pp. 490-499.

Edwards, L. and Muir, E.J. (2012), "Evaluating enterprise education: why do it?", Education + Training, in Harte, V. (Ed.), Vol. 54 No. 4, pp. 278-290.

Elert, N., Andersson, F.W. and Wennberg, K. (2015), "The impact of entrepreneurship education in high school on long-term entrepreneurial performance", Journal of Economic Behavior and Organization, Vol. 111, pp. 209-223.

Farmer, S.M., Yao, X. and Kung-Mcintyre, K. (2011), "The behavioral impact of entrepreneur identity aspiration and prior entrepreneurial experience", Entrepreneurship Theory and Practice, Vol. 35 No. 2, pp. 245-273.

Fayolle, A. (2013), "Personal views on the future of entrepreneurship education", Entrepreneurship \& Regional Development, Vol. 25 Nos 7-8, pp. 692-701.

Florin, J., Karri, R. and Rossiter, N. (2007), "Fostering entrepreneurial drive in business education: an attitudinal approach", Journal of Management Education, Vol. 31 No. 1, pp. 17-42.

Gecas, V. (1982), "The self-concept", Annual Review of Sociology, Vol. 8 No. 1, pp. 1-33.

Gird, A. and Bagraim, J.J. (2008), "The theory of planned behaviour as predictor of entrepreneurial intent amongst final-year university students", South African Journal of Psychology, Vol. 38 No. 4, pp. 711-724. 
Goktan, A.B. and Gupta, V.K. (2015), "Sex, gender, and individual entrepreneurial orientation: evidence from four countries", International Entrepreneurship and Management Journal, Vol. 11 No. 1, pp. 95-112.

Gregori, P., Holzmann, P. and Wdowiak, M.A. (2021), "For the sake of nature: identity work and meaningful experiences in environmental entrepreneurship", Journal of Business Research, Vol. 122, pp. 488-501.

Gupta, V.K., Niranjan, S., Goktan, B.A. and Eriskon, J. (2016), "Individual entrepreneurial orientation role in shaping reactions to new technologies", International Entrepreneurship and Management Journal, Vol. 12 No. 4, pp. 935-961.

Hair, J.F. Jr, Black, W.C., Babin, B.J. and Anderson, R.E. (2014), Multivariate Data Analysis: Pearson New International Edition, 7th ed., Pearson, Harlow.

Hamilton, R.T. and Harper, D.A. (1994), "The entrepreneur in theory and practice", Journal of Economic Studies, Vol. 21 No. 6, pp. 3-18.

Harman, H.H. (1967), Modern Factor Analysis, 2nd ed., University of Chicago Press, Chicago.

Harmeling, S.S. (2011), "Re-storying an entrepreneurial identity: education, experience and selfnarrative", Education + Training, Vol. 53 Nos 8-9, pp. 741-749.

Helmreich, R.L. and Spence, J.T. (1978), "The work and family orientation questionnaire: an objective instrument to assess components of achievement motivation and attitudes toward family and career", JSAS Catalog of Selected Documents in Psychology, Vol. 8 No. 35, pp. 7-74.

Hoang, H. and Gimeno, J. (2010), "Becoming a founder: how founder role identity affects entrepreneurial transitions and persistence in founding", Journal of Business Venturing, Vol. 25 No. 1, pp. 41-53.

Holzmann, P., Hartlieb, E. and Roth, M. (2018), "From engineer to entrepreneur - entrepreneurship education for engineering students: the case of the entrepreneurial campus Villach", International Journal of Engineering Pedagogy (IJEP), Vol. 8 No. 3, pp. 28-39.

Hughes, M. and Morgan, R.E. (2007), "Deconstructing the relationship between entrepreneurial orientation and business performance at the embryonic stage of firm growth", Industrial Marketing Management, Vol. 36 No. 5, pp. 651-661.

Hytti, U. and Heinonen, J. (2013), "Heroic and humane entrepreneurs: identity work in entrepreneurship education”, Education + Training, Vol. 55 Nos 8-9, pp. 886-898.

Kassean, H., Vanevenhoven, J., Liguori, E. and Winkel, D.E. (2015), "Entrepreneurship education: a need for reflection, real-world experience and action", International Journal of Entrepreneurial Behavior and Research, Vol. 21 No. 5, pp. 690-708.

Kirzner, I.M. (1973), Competition and Entrepreneurship, University of Chicago Press, Chicago.

Kollmann, T., Christofor, J. and Kuckertz, A. (2007), "Explaining individual entrepreneurial orientation: conceptualisation of a cross-cultural research framework", International Journal of Entrepreneurship and Small Business, Vol. 4 No. 3, p. 325.

Kristiansen, S. and Indarti, N. (2004), "Entrepreneurial intention among Indonesian and Norwegian students", Journal of Enterprising Culture, Vol. 12 No. 1, pp. 55-78.

Krueger, N.F. (2007), "What lies beneath? The experiential essence of entrepreneurial thinking", Entrepreneurship Theory and Practice, Vol. 31 No. 1, pp. 123-138.

Langkamp Bolton, D. and Lane, M.D. (2012), "Individual entrepreneurial orientation: development of a measurement instrument", Education + Training, Vol. 54 Nos 2-3, pp. 219-233.

Lattacher, W., Gregori, P., Holzmann, P. and Schwarz, E.J. (2021), "Knowledge spillover in entrepreneurial emergence: a learning perspective", Technological Forecasting and Social Change, Vol. 166, p. 120660.

Liñán, F., Ceresia, F. and Bernal, A. (2018), "Who intends to enroll in entrepreneurship education? entrepreneurial self-identity as a precursor", Entrepreneurship Education and Pedagogy, Vol. 1 No. 3, pp. 222-242. 
ET

$63,7 / 8$

1190

Liu, Y., Liu, J. and Wu, L. (2010), "Are you willing and able? roles of motivation, power, and politics in career growth", Journal of Management, Vol. 36 No. 6, pp. 1432-1460.

Lumpkin, G.T. and Dess, G.G. (1996), "Clarifying the entrepreneurial orientation construct and linking it to performance", Academy of Management Review, Vol. 21 No. 1, pp. 135-172.

Markman, G.D., Baron, R.A. and Balkin, D.B. (2005), "Are perseverance and self-efficacy costless? Assessing entrepreneurs' regretful thinking”, Journal of Organizational Behavior, Vol. 26 No. 1, pp. 1-19.

Markus, H. and Nurius, P. (1986), "Possible selves”, American Psychologist, Vol. 41 No. 9, pp. 954-969.

McClelland, D.C. (1975), The Achieving Society, Irvington Publishers, New York.

Mmbaga, N.A., Mathias, B.D., Williams, D.W. and Cardon, M.S. (2020), "A review of and future agenda for research on identity in entrepreneurship", Journal of Business Venturing, Vol. 35 No. 6, p. 106049 .

Mungai, E. and Velamuri, S.R. (2011), "Parental entrepreneurial role model influence on male offspring: is it always positive and when does it occur?", Entrepreneurship Theory and Practice, Vol. 35 No. 2, pp. 337-357.

Murnieks, C.Y., Mosakowski, E. and Cardon, M.S. (2014), "Pathways of passion: identity centrality, passion, and behavior among entrepreneurs", Journal of Management, Vol. 40 No. 6, pp. 1583-1606.

Murnieks, C.Y., McMullen, J.S. and Cardon, M.S. (2019), "Does congruence with an entrepreneur social identity encourage positive emotion under environmental dynamism?", Journal of Small Business Management, Vol. 57 No. 3, pp. 872-890.

Murnieks, C.Y., Klotz, A.C. and Shepherd, D.A. (2020), "Entrepreneurial motivation: a review of the literature and an agenda for future research", Journal of Organizational Behavior, Vol. 41 No. 2, pp. 115-143.

Murray, H.A. (2008), Explorations in Personality, 70th Anniv, Oxford University Press, Oxford.

Nabi, G., Liñán, F., Fayolle, A., Krueger, N. and Walmsley, A. (2017), “The impact of entrepreneurship education in higher education: a systematic review and research agenda", Academy of Management Learning and Education, Vol. 16 No. 2, pp. 277-299.

Neck, H., Greene, P. and Brush, C. (2014), Teaching Entrepreneurship: A Practice-Based Approach, Edward Elgar Publishing, Northampton, MA, doi: 10.4337/9781782540564.

Neneh, B.N. (2019), "From entrepreneurial alertness to entrepreneurial behavior: the role of trait competitiveness and proactive personality", Personality and Individual Differences, Vol. 138, pp. 273-279.

Netemeyer, R., Bearden, W. and Sharma, S. (2003), Scaling Procedures: Issues and Applications, SAGE, Thousand Oaks California.

Newbery, R., Lean, J., Moizer, J. and Haddoud, M. (2018), "Entrepreneurial identity formation during the initial entrepreneurial experience: the influence of simulation feedback and existing identity", Journal of Business Research, Vol. 85, pp. 51-59.

Newman, A., Obschonka, M., Schwarz, S., Cohen, M. and Nielsen, I. (2019), "Entrepreneurial selfefficacy: a systematic review of the literature on its theoretical foundations, measurement, antecedents, and outcomes, and an agenda for future research", Journal of Vocational Behavior, Vol. 110, pp. 403-419.

OEAD (2020), "The austrian education system", available at: https://www.bildungssystem.at/en (accessed 16 December 2020).

O'brien, R.M. (2007), “A caution regarding rules of thumb for variance inflation factors”, Quality and Quantity, Vol. 41 No. 5, pp. 673-690.

Pfeifer, S., Šarlija, N. and Zekić Sušac, M. (2016), "Shaping the entrepreneurial mindset: entrepreneurial intentions of business students in Croatia”, Journal of Small Business Management, Vol. 54 No. 1, pp. 102-117. 
Podsakoff, P.M., MacKenzie, S.B., Lee, J.Y. and Podsakoff, N.P. (2003), "Common method biases in behavioral research: a critical review of the literature and recommended remedies", Journal of Applied Psychology, Vol. 88 No. 5, pp. 879-903.

Pruett, M. and Şeşen, H. (2017), "Faculty-student perceptions about entrepreneurship in six countries", Education + Training, Vol. 59 No. 1, pp. 105-120.

Rajabi, R., Brashear-Alejandro, T. and Chelariu, C. (2018), "Entrepreneurial motivation as a key salesperson competence: trait antecedents and performance consequences", Journal of Business and Industrial Marketing, Vol. 33 No. 4, pp. 405-416.

Rauch, A. and Frese, M. (2007), "Let's put the person back into entrepreneurship research: a metaanalysis on the relationship between business owners' personality traits, business creation, and success", European Journal of Work and Organizational Psychology, Vol. 16 No. 4, pp. 353-385.

Rezaei, J. and Ortt, R. (2018), "Entrepreneurial orientation and firm performance: the mediating role of functional performances”, Management Research Review, Vol. 41 No. 7, pp. 878-900.

Sahoo, S. and Panda, R.K. (2019), "Exploring entrepreneurial orientation and intentions among technical university students", Education + Training, Vol. 61 No. 6, pp. 718-736.

Schumpeter, J.A. (1934), The Theory of Economic Development: an Inquiry into Profits, Capital, Credit, Interest and the Business Cycle, Harvard University Press, Cambridge.

Şeşen, H. and Pruett, M. (2014), "Nascent entrepreneurs: gender, culture, and perceptions", Journal of Women's Entrepreneurship and Education, Vol. 3 No. 4, pp. 1-21.

Seibert, S.E., Nielsen, J.D. and Kraimer, M.L. (2020), "Awakening the entrepreneur within: entrepreneurial identity aspiration and the role of displacing work events", Journal of Applied Psychology, Advance online publication, pp. 1-15.

Shaver, K.G. and Scott, L.R. (1992), "Person, process, choice: the psychology of new venture creation", Entrepreneurship Theory and Practice, Vol. 16 No. 2, pp. 23-46.

Spence, J.T. and Helmreich, R.L. (1983), "Achievement-related motives and behaviour”, in Spence, J.T. (Ed.), Achievement and Achievement Motives: Psychological and Sociological Approaches, Freeman, San Francisco, pp. 7-74.

Stets, J.E. and Burke, P.J. (2000), "Identity theory and social identity theory", Social Psychology Quarterly, Vol. 63 No. 3, pp. 224-237.

Stewart, W.H., Watson, W.E., Carland, J.C. and Carland, J.W. (1999), "A proclivity for entrepreneurship”, Journal of Business Venturing, Vol. 14 No. 2, pp. 189-214.

Stryker, S. (1968), "Identity salience and role performance: the relevance of symbolic interaction theory for family research", Journal of Marriage and the Family, Vol. 30 No. 4, p. 558.

Stryker, S. and Burke, P.J. (2000), "The past, present, and future of an identity theory", Social Psychology Quarterly, Vol. 63 No. 4, pp. 284-297.

Swail, J., Down, S. and Kautonen, T. (2014), "Examining the effect of 'entre-tainment' as a cultural influence on entrepreneurial intentions", International Small Business Journal: Researching Entrepreneurship, Vol. 32 No. 8, pp. 859-875.

Taatila, V. and Down, S. (2012), "Measuring entrepreneurial orientation of university students", Education + Training, Vol. 54 Nos 8-9, pp. 744-760.

Tripathi, N., Zhu, J., Jacob, G.H., Frese, M. and Gielnik, M.M. (2020), "Intraindividual variability in identity centrality: examining the dynamics of perceived role progress and state identity centrality", Journal of Applied Psychology, Vol. 105 No. 8, pp. 889-906.

Wagenschwanz, A.M. (2020), "The identity of entrepreneurs: providing conceptual clarity and future directions", International Journal of Management Reviews, pp. 1-21.

Weger, I. (2020), “Unterrichtsprinzipien”, available at: https://hak.cc/persoenlichkeitsentwicklung/ unterrichtsprinzipien (accessed 16 December 2020). 
Wolfe, M.T. and Shepherd, D.A. (2015), “Bouncing back' from a loss: entrepreneurial orientation, emotions, and failure narratives", Entrepreneurship Theory and Practice, Vol. 39 No. 3, pp. 675-700.

Zapkau, F.B., Schwens, C. and Kabst, R. (2017), "The role of prior entrepreneurial exposure in the entrepreneurial process: a review and future research implications", Journal of Small Business Management, Vol. 55 No. 1, pp. 56-86.

1192

Zhang, P., Wang, D.D. and Owen, C.L. (2015), "A study of entrepreneurial intention of university students", Entrepreneurship Research Journal, Vol. 5 No. 1, pp. 61-82.

Zhao, H., Seibert, S.E. and Hills, G.E. (2005), "The mediating role of self-efficacy in the development of entrepreneurial intentions", Journal of Applied Psychology, Vol. 90 No. 6, pp. 1265-1272. 


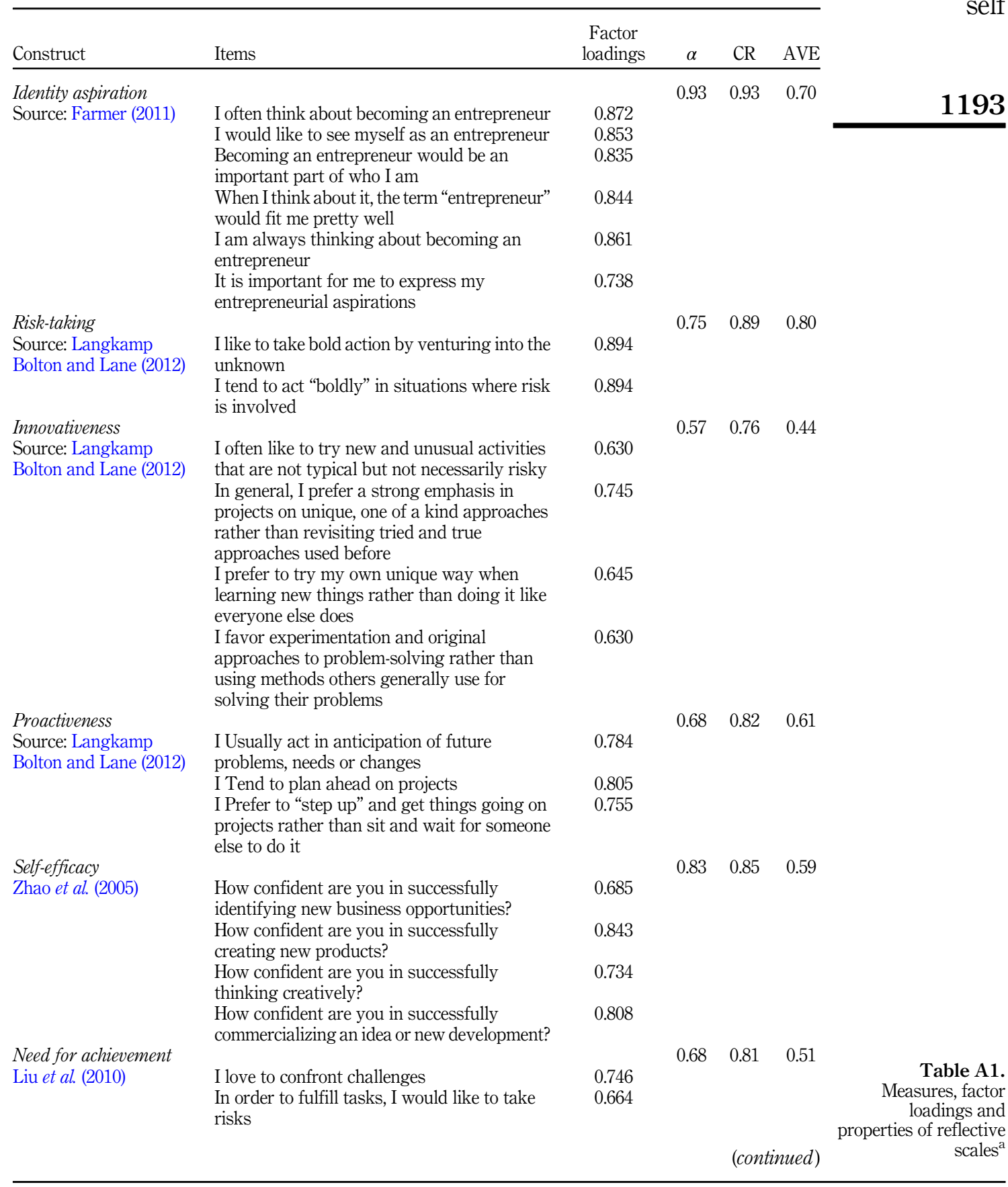


ET

$63,7 / 8$

\begin{tabular}{|c|c|c|c|c|c|}
\hline Construct & Items & $\begin{array}{l}\text { Factor } \\
\text { loadings }\end{array}$ & $\alpha$ & CR & AVE \\
\hline \multirow{9}{*}{$\begin{array}{l}\text { Competitiveness } \\
\text { Helmreich and Spence } \\
\text { (1978) }\end{array}$} & I am willing to set and achieve realistic goals & 0.786 & \multirow{9}{*}{0.83} & \multirow{9}{*}{0.87} & \multirow{9}{*}{0.57} \\
\hline & I would like to seek satisfaction from & 0.662 & & & \\
\hline & accomplishing a difficult task & & & & \\
\hline & I eniov working in situations involving & 0717 & & & \\
\hline & competition with others & 0.11 & & & \\
\hline & $\begin{array}{l}\text { It is important to me to perform better than } \\
\text { others on a task }\end{array}$ & 0.806 & & & \\
\hline & $\begin{array}{l}\text { I Feel that winning is important in both work } \\
\text { and games }\end{array}$ & 0.760 & & & \\
\hline & $\begin{array}{l}\text { It annoys me when other people perform } \\
\text { better than I do }\end{array}$ & 0.795 & & & \\
\hline & $\begin{array}{l}\text { I Try harder when I am in competition with } \\
\text { other people }\end{array}$ & 0.704 & & & \\
\hline
\end{tabular}

Corresponding author

Patrick Gregori can be contacted at: patrick.gregori@aau.at

For instructions on how to order reprints of this article, please visit our website: www.emeraldgrouppublishing.com/licensing/reprints.htm Or contact us for further details: permissions@emeraldinsight.com 